\title{
PENGAJARAN DARING PROTOKOL KESEHATAN INDUSTRI HOTELBAGI SISWA-SISWI VOKASI PERHOTELAN
}

\author{
Yoanira Alexandra ${ }^{1}$, Ringkar Situmorang ${ }^{2}$ \\ ${ }^{1}$ Universitas Multimedia Nusantara
}

Yoanita.alexandra@umn.ac.id, ringkar.situmorang@umn.ac.id

\begin{abstract}
Abstrak
Dampak pandemi COVID-19 sangat berpengaruh pada sektor pariwisata. Sektor pendidikan pariwisata juga terkena imbasnya, terlepas dari pengajaran yang dilakukan secara virtual dan berkurangnya kelas praktik, rekrutmen serta program magang juga semakin dipersulit. Penerimaan siswa-siswi baru, sponsor industri dan pemerintah, serta pendanaan penelitian pariwisata juga berkurang secara drastis. Padahal, pendidikan vokasi merupakan prioritas bagi pemerintah untuk meningkatkan keterampilan professional sumber daya manusia Indonesia agar mempunyai daya saing. Institusi pendidikan vokasi di Kabupaten Tangerang melihat adanya kebutuhan pembekalan bagi siswa-siswi vokasi agar lebih berani dan bertambah wawasannya akan protokol kesehatan dalam industri perhotelan selama masa pandemi. Untuk menjawab persoalan tersebut, kegiatan pengabdian kepada masyarakat ini dilaksanakan. Kegiatan terbagi menjadi tiga tahap, yaitu persiapan, pengajaran secara daring, dan kegiatan pasca-pengajaran. Hasil dari kegiatan ini berupa modul protokol kesehatan industri perhotelan, poster protokol kesehatan, serta video hotel new normal yang dapat digunakan siswa-siswi vokasi sebagai panduan protokol kesehatan dalam bekerja di industri perhotelan. Manfaat dari pengajaran daring ini adalah memberikan wawasan terbaru mengenai kondisi industri perhotelan dan protokolprotokol kesehatan new normal kepada siswa-siswi vokasi, sehingga diharapkan semakin siap dalam terjun bekerja dalam industri perhotelan.
\end{abstract}

Kata Kunci : Pendidikan vokasi, protokol kesehatan, COVID-19, Pariwisata

\section{PENDAHULUAN}

Penyakit Coronavirus atau COVID-19 merupakan penyakit baru yang dapat menyebabkan gangguan pernapasan dan pneumonia (Japutra \& Situmorang, 2021). Penyakit ini cepat menyebar dan bisa mengakibatkan kematian. Virus ini pertama kali dilaporkan ke Organisasi Kesehatan Dunia (WHO) pada 31 Desember 2019. Pada Maret 2020, WHO mengumumkan wabah COVID-19 sebagai pandemi. Dampak pandemi ini menciptakan tekanan yang signifikan pada lapangan pekerjaan di sektor pariwisata. Pendidikan pariwisata secara tidak langsung ikut terpengaruh dampak yang diciptakan (Ye \& Law, 2021).

Terlepas dari pengajaran yang dilakukan secara virtual dan berkurangnya waktu praktik, siswa-siswi vokasi, mahasiswa dan lulusan pariwisata lainnya juga harus mengatasi penghentian program magang atau on-the job training, rekrutmen yang semakin sulit serta jalur karir pariwisata yang semakin dipertanyakan (Soemarni, Situmorang, Guna, 2019). Program vokasi pariwisata juga dihadapkan pada 
berkurangnya penerimaan siswa, sponsor industri dan pemerintah, serta pendanaan penelitian. (Sigala, 2020).

Pendidikan vokasi menjadi prioritas pemerintah Indonesia dalam upaya meningkatkan sumber daya manusia agar memiliki daya saing dan keterampilan yang unggul. Pendidikan vokasi secara umum dapat didefinisikan sebagai bentuk pendidikan yang memberikan pengetahuan dan keterampilan profesional secara khusus (Kotsikis, 2007). Pendidikan ini merupakan salah satu bagian dari strategi pendidikan nasional untuk dapat mewujudkan tenaga kerja dalam negri yang terampil dan terkualifikasi. Upaya yang dapat dilakukan adalah dengan menyediakan pelatihanpelatihan yang dibutuhkan, membentuk kepribadian, atribut personal, dan keterampilan khusus. Pengabdian Kepada Masyarakat ini terfokus pada penyediaan pelatihan bagi siswa vokasi industri pariwisata. Kegiatan ini akan diadakan secara daring, untuk mendukung pembatasan sosial skala besar yang terjadi di Indonesia.

\section{METODE}

Kegiatan Pengabdian Masyarakat dikemas dalam bentuk Pengajaran Daring yang berjudul "Mempersiapkan Generasi Baru Hotelier". Pelaksanaan pengabdian dibagi mejadi tiga tahap, yaitu persiapan, pengajaran, serta pascapengajaran..

Tahap persiapan dilaksanakan mulai dari tanggal 3 Maret 2021. Persiapan acara meliputi proses peninjauan mitra pengabdian, penetapan panitia acara, pembuatan materi, pembuatan proposal, surat undangan serta proses komunikasi dengan narasumber ataupun pihak sekolah vokasi yang ada di Tangerang. Kegiatan pengajaran dilakukan secara daring menggunakan aplikasi video-conferencing "Zoom", yang diselenggarakan pada hari Jumat, tanggal 16 April 2021. Berikut merupakan peserta yang hadir dalam kegiatan pengajaran.

Tabel 1. Peserta Kegiatan

\begin{tabular}{lrr}
\hline \multicolumn{1}{c}{ Asal Institusi Peserta } & Jumlah & Presentase \\
\hline SMKN 7 Kab Tangerang & 76 & $69 \%$ \\
SMKN 3 Tangerang & 2 & $2 \%$ \\
SMK IPTEK Tangsel & 2 & $2 \%$ \\
Greenotel Cilegon & 1 & $1 \%$
\end{tabular}

\begin{tabular}{lrr}
$\begin{array}{l}\text { Universitas } \\
\text { Nusantara }\end{array}$ & 29 & $26 \%$ \\
\hline \multicolumn{1}{c}{ Status dalam Institusi } & Jumlah & Presentase \\
\hline Siswa/Mahasiswa Vokasi & 89 & $81 \%$ \\
Guru/Dosen & 13 & $12 \%$ \\
Lainnya & 8 & $7 \%$ \\
\hline
\end{tabular}

Metode pengajaran dilaksanakan dalam rupa ruang kelas dalam bentuk penyampaian materi serta diskusi dan tanya jawab. Materi protokol juga dilengkapi dengan video protokol kesehatan agar lebih dipahami oleh siswa-siswi vokasi. Adapun materi pengajaran protokol kesehatan dibagi dalam dua garis besar topik, yaitu protokol pada Room Division dan juga pada Food and Beverage Department. Adapun 11 (sebelas) pembahasan yang diberikan sebagai materi pengajaran, yaitu:

Tabel 2. Susunan Materi Pengajaran

\begin{tabular}{|c|c|c|}
\hline No. & Topik & Konten Materi \\
\hline 1. & $\begin{array}{l}\text { Protokol } \\
\text { Kesehatan } \\
\text { pada Room } \\
\text { Division / } \\
\text { Divisi Kamar }\end{array}$ & $\begin{array}{l}\text { - Protokol dengan Staff } \\
\text { - Protokol dengan Tamu } \\
\text { - Protokol dengan Fasilitas dan } \\
\text { Kamar }\end{array}$ \\
\hline 2. & $\begin{array}{l}\text { Protokol } \\
\text { Kesehatan } \\
\text { pada Food } \\
\text { and Beverage } \\
\text { Department }\end{array}$ & $\begin{array}{l}\text { - Operasional F\&B pada New } \\
\text { Normal } \\
\text { - Mengatur Kesehatan dan } \\
\text { Keamanan untuk karyawan saat } \\
\text { bekerja } \\
\text { - Kebersihan dan standard } \\
\text { grooming karyawan } \\
\text { - Mengatur jasa operasional } \\
\text { restoran } \\
\text { - Standar kebersihan dan sanitasi } \\
\text { untuk F\&B Departemen di New } \\
\text { Normal } \\
\text { - CHSE Cleanliness (Kebersihan), } \\
\text { Health (Kesehatan), Safety } \\
\text { (Keamanan), dan Environment } \\
\text { Sustainability (Kelestarian } \\
\text { Lingkungan) } \\
\text { - Penerapan CHSE di Hotel }\end{array}$ \\
\hline
\end{tabular}

Pada tahap terakhir yaitu pasca-pengajaran, dilakukan tinjau langsung ke salah satu mitra pengabdian, yaitu SMKN 7 Kabupaten Tangerang. Kegiatan dilaksanakan dengan tujuan evaluasi dan diskusi serta penyerahan materi fisik maupun digital. Acara ditutup dengan foto bersama dan penyerahan plakat. 


\section{HASIL DAN PEMBAHASAN}

\section{Paparan dan Diskusi}

Berikut merupakan hasil dan pembahasan dari proses pengajaran daring dalam bentuk seminar serta diskusi tanya jawab.

a. Protokol kesehatan dalam bekerja di industri hotel saat new normal telah berubah. Siswasiswi vokasi diajarkan tentang bahaya pandemi COVID-19 dan bagaimana seorang staff hotel harus mengikuti protokol kesehatan yang ada. Seperti menggunakan sarung tangan, masker, dan pelindung wajah, cek suhu tubuh sebelum bekerja, meminimalisir sentuhan dan kontak fisik, sering mencuci tangan menggunakan sabun, rajin menggunakan hand-sanitizer, memastikan penggunaan seragam untuk satu kali pakai, meminimalisir interaksi dengan tamu atau sesame staff, mengikuti penyuluhan seputar COVID-19 di tempat kerja, dan lain sebagainya.

b. Tamu hotel mempunyai potensi sebagai pembawa virus COVID-19, karena itu beberapa protokol baru harus disiapkan oleh hotel dan para pekerja hotel. Salah satunya adalah mewajibkan pemakaian masker di ruang terbuka umum hotel, cek suhu tubuh tamu yang datang ke hotel, penggunaan hand-sanitizer dan lain sebagainya. Selain itu, pihak hotel juga harus siap untuk menanggapi resiko yang terjadi dan membantu tamu jika terindikasi COVID-19, menyediakan ruang isolasi, perawat dan dokter panggilan, serta berkoordinasi dengan pihak Rumah Sakit terdekat.

c. Fasilitas dan kamar hotel dapat menjadi resiko penularan, baik dari tamu ke staff hotel dan sebaliknya. Proses pembersihan dan sanitasi harus dilaksanakan sesuai dengan standar kesehatan, seperti penggunaan disinfektan dalam proses pembersihan kamar, tersedianya handsanitizer dengan minimum $70 \%$ kadar alkohol, pemisahan linen kotor dan linen bersih, pencucian linen kotor dengan suhu tinggi dan menggunakan chemical terstandar, memberikan perhatian khusus untuk selalu memberikan disinfektan pada gagang pintu, saklar listrik, toilet, dan fasilitas lain yang bersentuhan, menjaga $\mathrm{PH}$, temperature dan level klorin pada kolam renang sesuai dengan standar, serta meminimalisir kegiatan pada public area.

d. Restoran juga merupakan salah satu fasilitas hotel yang beresiko menjadi tempat penularan. Siswa-siswi vokasi diajarkan pentingnya protokol kesehatan dalam F\&B Department dan bagaimana makanan dan minuman sangat rentan dan beresiko menjadi media penularan. Staff restoran, baik yang bekerja sebagai server atau pelayan restoran dan juga koki dapur, harus memahami resiko ini dalam bekerja dan harus tetap memastikan protokol kesehatan dijalankan oleh tamu dan juga sesama karyawan.

e. Selain protokol kesehatan, kebiasaan-kebiasaan staff saat bekerja juga perlu diperhatikan. Seperti menerapkan standar grooming hotel, menutup hidung dan mulut ketika bersin atau batuk, rajin mencuci tangan, terutama sebelum menangani makanan dan juga setelah batuk dan bersin, tidak membuka masker dan penutup wajah (face mask) saat bekerja dan juga menghindari untuk memegang mata, hidung, ataupun mulut saat bekerja.

f. Dalam penanganan operasional restoran, karyawan harus memperhatikan kebersihan dan keamanan makanan (food hygiene and safety) baik dalam proses persiapan, pemasakan sampai hasil akhir. Proses penyajian makanan ke tamu restoran serta sampai akhir piring kotor kembali ke dapur untuk dicuci harus diperhatikan dalam penanganannya. Kebersihan restoran, meja dan kursi, counter kasir, lantai, gelas, cangkir, serta alat makan harus tersanitasi dengan baik.

g. Siswa-siswi vokasi juga diajarkan, bahwa koki di dapur harus dapat mengolah makanan menggunakan standar HACCP (Hazard Analytical Control Point) untuk menghindari adanya kontaminasi. Selain itu kebersihan alat dapur harus lebih diperhatikan. Menghilangkan menu dengan makanan mentah juga sangat direkomendasikan. Di restoran juga harus diterapkan physical distancing atau jarak fisik antara tamu, serta membatasi jumlah tamu yang bisa makanan di dalam restoran. Penanganan menu buffet juga harus diperhatikan dan dilayani langsung oleh staff restoran dengan memperhatikan protokol yang ada. Buku menu dalam restoran dapat disediakan dalam bentuk 
soft copy atau QR code, dan jika memiliki buku menu fisik dapat dibersihkan secara berkala.

h. Hotel-hotel di Indonesia telah menerapkan CHSE. Sangat penting bagi siswa-siswi vokasi untuk mengetahui lebih dalam mengenai CHSE. CHSE adalah kepanjangan dari Cleanliness, Health, Safety, and Environment Sustainability; merupakan protokol kebersihan, kesehatan, keselamatan, dan kelestarian lingkungan yang dikeluarkan oleh Kementerian Pariwisata dan Ekonomi Kreatif sebagai pedoman bagi para pelaku di bidang Pariwisata dan Ekonomi Kreatif. Penerapan ini disahkan dalam suatu sertifikasi yang memastikan hotel yang memiliki sertifikasi ini terjamin dalam penerapan protokol sesuai standar CHSE.

i. Dalam aspek cleanliness (kebersihan), hotel harus menyediakan sarana cuci tangan, pembersihan ruangan serta fasilitas public dengan disinfektan, pembesihan tempat sampah, serta bebas dari hama dan hewan pembawa penyakit. Dalam aspek health (kesehatan), hotel harus menjaga protokol kesehatan untuk pekerja dan juga tamu hotel. Seperti pengecekan suhu tubuh, penggunaan masker, mencegah kerumunan, pengaturan jarak aman, sirkulasi udara yang baik, dan lain sebagainya. Dalam aspek safety (keselamatan), hotel diharuskan memiliki prosedur penyelamatan diri dari bencana, ketersediaan alat P3K, ketersediaan alat pemadam kebakaran, titik kumpul dan jalur evakuasi, serta mekanisme penanganan dalam kondisi darurat.

j. Yang terakhir dalam aspek environmental sustainability (kelestarian lingkungan), hotel harus memastikan penggunaan perlengkapan serta bahan ramah lingkungan, pemanfaatan air dan energy secara efisien, pengolahan sampah dan limbah dilakukan secara sehat dan ramah lingkungan, serta kondisi lingkungan sekitar hotel asri dan nyaman.

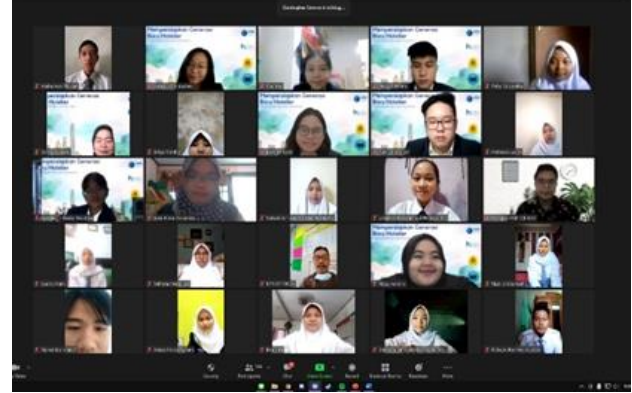

Gambar 1. Peserta pengajaran daring 1

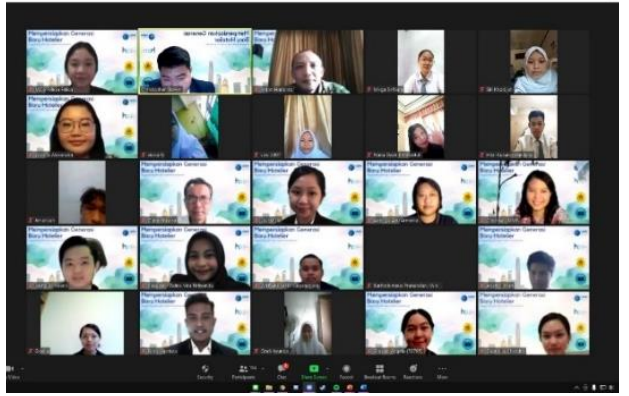

Gambar 2. Peserta pengajaran daring 2

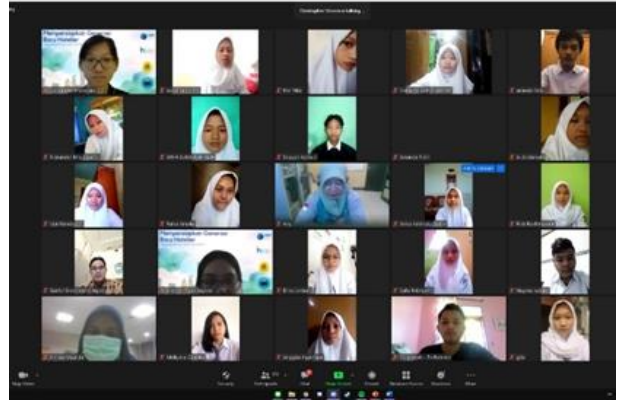

Gambar 3 . Peserta pengajaran daring 3

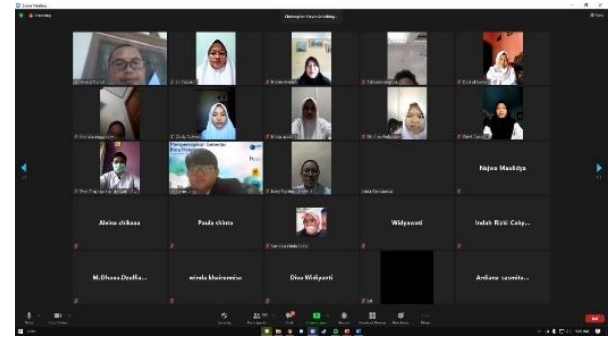

Gambar 4. Peserta pengajaran daring 4 


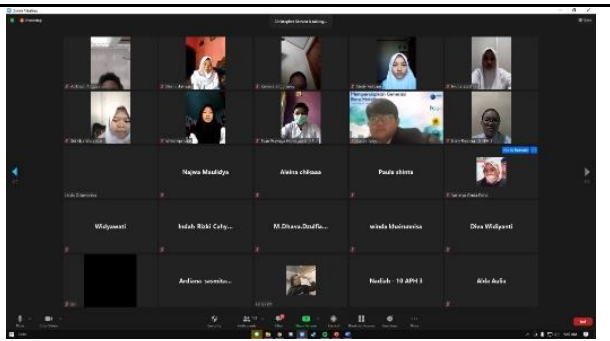

Gambar 5. Peserta pengajaran daring 5

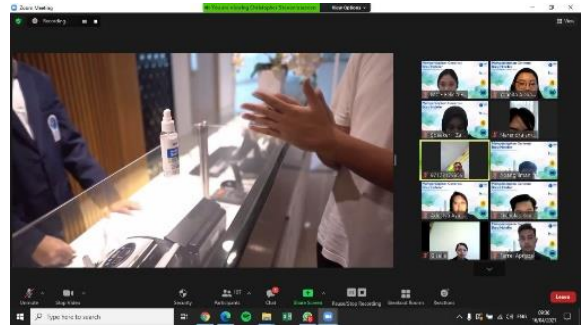

Gambar 6. Pemutaran video protokol

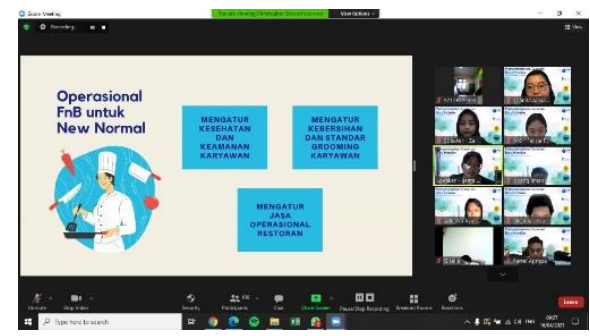

Gambar 7. Proses pengajaran daring

\section{Kegiatan Pasca-Pengajaran}

Setelah proses pengajaran secara daring, dilakukan visitasi langsung kepada salah satu mitra PKM yaitu SMKN 7 Kabupaten Tangerang. Pertemuan secara langsung dilakukan untuk diskusi dan evaluasi hasil dari kegiatan pengajaran secara online. Selain itu, untuk dapat menunjang penyerapan ilmu, kegiatan ini turut memberikan buku modul protokol kesehatan pada divisi kamar dan F\&B department, baik secara fisik maupun secara soft-copy, serta poster-poster protokol kesehatan sebagai pengingat yang dapat ditempel di sekitar sekolah. Diharapkan buku modul dan poster ini dapat digunakan siswa-siswi vokasi sebagai acuan dalam protokol kesehatan pada industri perhotelan.

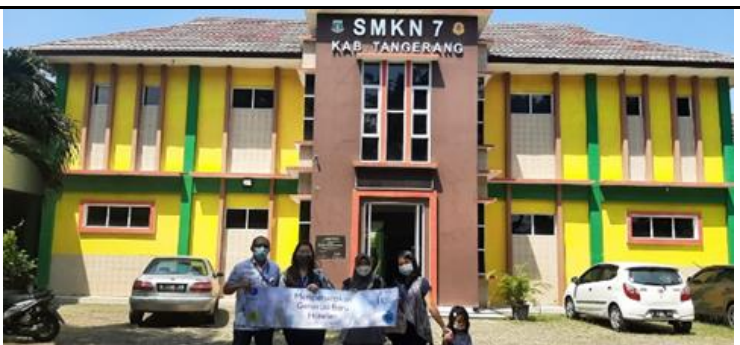

Gambar 8. Kunjungan ke pihak mitra PKM

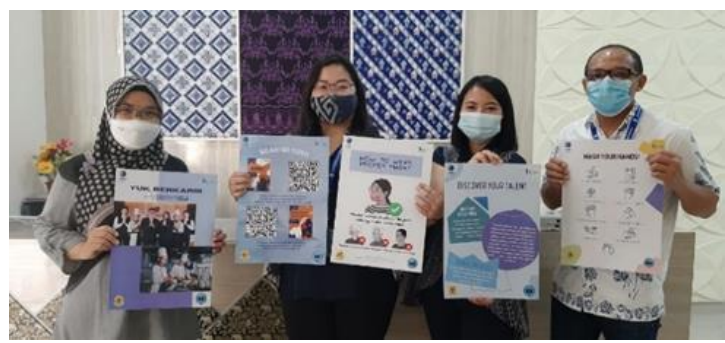

Gambar 9. Penyerahan fisik poster protokol

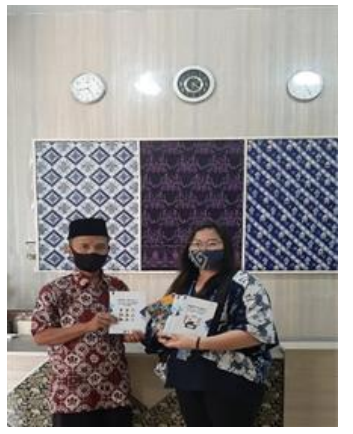

Gambar 10. Penyerahan buku modul protokol kesehatan

\section{KESIMPULAN}

Dari kegiatan Pengabdian Kepada Masyarakat ini dapat disimpulkan:

1. Siswa-siswi vokasi yang hadir dalam pengajaran online merasa lebih siap dalam menghadapi praktik kerja nyata dan terjun sebagai tenaga kerja di industri hotel. Hal ini dapat dilihat dari antusiasme mereka dan keaktifan mereka saat sesi diskusi dan tanya jawab.

2. Peserta merasa puas dan terbekali setelah mengikuti rangkaian materi pengajaran online. Ditambah mereka memiliki modul protokol yang dapat mereka buka kapan saja, disaat mereka membutuhkan. 
3. Pihak mitra PKM juga merasa puas, karena memiliki tambahan materi pengajaran dari sisi hotel yang terbaru, ditambah, modul, video, serta poster dapat dimanfaatkan dan digunakan untuk penggunaan sekolah untuk seterusnya.

4. Luaran setelah mengikuti pengajaran daring ini, diharapkan siswa-siswi vokasi dapat terus melanjutkan mimpinya dalam berkarir di industri perhotelan, dan melahirkan generasigenerasi penerus hotel yang baru.

\section{REFERENSI}

Japutra, A., \& Situmorang, R. (2021). The repercussion and challenges of COVID-19 in hotel industry: Potential strategies from a case study of Indonesia. International Journal of Hospitality Management, 95, 102890

Kotsikis, V. (2007). Educational Administration and Policy. Athens: Ellin.
Sigala, M. (2020). Tourism and COVID-19: Impacts and implications for advancing and resetting industry and research. Journal of Business Research, Volume 117 , https://doi.org/10.1016/j.jbusres.2020.06.015.

Soemarni, L., Situmorang, R., \& Guna, A. (2019). Workshop Pengayaan Materi Praktik Kerja Industri bagi Siswa SMK Ancop Desa Kawalelo. Prosiding PKM-CSR, Vol. 2, 958-966.

Ye, H., \& Law, R. (2021). Impact of COVID-19 on hospitality and tourism education: a case study of Hong kong. Journal of Teaching in Travel \& Tourism, DOI: https://doi.org/10.1080/15313220.2021.1875967 